\title{
Implementation of Evolution Strategies (ES) Algorithm to Optimization Lovebird Feed Composition
}

\author{
Agung Mustika Rizki ${ }^{1}$, Wayan Firdaus Mahmudy ${ }^{2}$, Gusti Eka Yuliastuti \\ ${ }^{123}$ Computer Science Department, Universitas Brawijaya, Malang \\ Email : ${ }^{1}$ agungmustikarizki@gmail.com, ${ }^{2}$ wayanfm@ub.ac.id, ${ }^{3}$ gustiekay@gmail.com
}

\begin{abstract}
Lovebird current society, especially popular among bird lovers. Some people began to try to develop the cultivation of these birds. In the cultivation process to consider the composition of feed to produce a quality bird. Determining the feed is not easy because it must consider the cost and need for vitamin Lovebird. This problem can be solved by the algorithm Evolution Strategies (ES). Based on test results obtained optimal fitness value of 0.3125 using a population size of 100 and optimal fitness value of 0.3267 in the generation of 1400 .
\end{abstract}

Keywords: Lovebird Cultivation, Feed Composition, Evolution Strategies

\section{INTRODUCTION}

Lovebird is one of nine species of the genus Agapornis [1]. The hallmark of this bird is a crooked beak and color patterns on the coat [1]. In some areas currently Lovebird is very popular. Starting from a hobby to clear land to make money by participating in various competitions. Breeding birds chirp like the type of Lovebird currently getting ogled by hobbyists birds chirp in the various regions. Skyrocketing sales price is also a trigger Lovebird breeders to develop optimally. Lovebird also a topic that is currently being discussed trends in the offline forums as well as online forums on the internet. Popularity factor that causes the bird prices soaring.

In the process raising a lovebird many things that need to be considered ranging from maintenance to feeding. In this case the feeding is not appropriate will greatly affect the quality of livestock [2]. However, to produce quality birds do not have to use expensive feed. Many feed at affordable prices which is enough to meet the nutritional Lovebird. If the optimization is done on feed Lovebird, it can increase profits. Such optimization is required to get quality feed at a price not too expensive so as to reduce the cost of care. This issue is important because the difference in price and / or there is a lack of quality nutrition can affect the entire Lovebird owned not just one bird alone.

Several studies have been done before by Endarwati [3] and Immaduddin [1] on the effect of aquaculture on the economy of communities in the city Lovebird respectively. From these studies it can be concluded that the cultivation of a lovebird can boost the economy in the region. But few of those farmers concerned about the composition of these birds feed their cattle. While the feed composition is optimal profit of cultivation will increase.

There are several methods of addressing this feed optimization problems namely Genetic Algorithm (GA) [4], Particle Swarm Optimization (PSO) [5], Simulated 
Annealing (SA) [6] and Evolution Strategies (ES) [7]. In this study the authors using Evolution Strategies (ES) since this method uses combinational solutions to obtain the optimal solution [8]. Besides, some previous studies also support the use of this method.

\section{METHODS}

\subsection{Related Work}

The first study conducted by Fakhiroh [4] by applying a genetic algorithm to mix fodder memperoles appropriate taking into account the nutritional and cost. In his research proved reliable genetic algorithms to solve the case of the composition of the food in cattle.

Another study conducted by Ramadan [5], which implement the algorithm Particle Swarm Optimization (PSO) for determining the allocation of capacitors on distribution systems with turbine. Although not on the same topic, but this algorithm can be an alternative to solve the problems in this study.

Another alternative method is Simulated Annealing algorithm (SA). This algorithm has been implemented by Demiroz [6] to calculate the cost of testing on a software. From these studies it can be seen that this method could be taken into account for the feed composition is implemented by the problem.

And the last is the research conducted by Milah [7] using Evolution Strategies (ES) to search for the best composition of animal feed. From these studies has proven reliable method to produce the fodder optimal recommendations.

From some research on the authors conclude that the ES algorithm can be used to solve problems in the feed composition lovebird.

\subsection{Lovebird Feed}

Lovebird requires a complete nutrition to support basic needs such as breathing, moving, circulatory, and others. In addition, it is also required nutrients Lovebird in production. Nutrition is in the form of protein, metabolizable energy, fat, fiber and calcium [9]. Overall these nutrients should be arranged in the right amount and balance in the form of food rations. To get the nutritional balance of the cattle, the type of feed used is a combination of millet, sunflower seeds, mustard greens, kale and corn. The combination of feed that meets the needs of livestock can produce animals with good quality. In this study there were five of feed to be optimized in order to get the greatest fitness value. The fifth feed is corn, kale, mustard, millet and sunflower seeds.

\subsection{Evolution Strategies (ES)}

Evolution Strategies (ES) is one branch of the Evolutionary Algorithm (EA). ES also adopted the theory of evolution [10]. In general, ES is almost the same as the Genetic 
Algorithm (GA). But there are differences; the process of reproduction. At GA, the main reproduction process using the crossover method, while the ES rely mutation. In addition, the representation of the solution of ES usually with fractions [10]. Generally, there are four types of processes in ES, namely: $(\mu, \lambda)$

$$
\begin{array}{ll}
- & (\mu / \mathrm{r}, \lambda) \\
- & (\mu+\lambda) \\
- & (\mu / \mathrm{r}+\lambda)
\end{array}
$$

In this study, the authors apply the type of $(\mu, \lambda)$. The purpose of the type of $(\mu, \lambda)$ is the reproduction process using only without recombination and mutation when making the selection involves only offspring alone [10].

Here are the stages in the ES [10]:

a. Chromosome Representation

Chromosome is a representation of the solution of a problem. In this ES, the authors apply real-coded representation in the form of fractions obtained randomly. Table 1 shows an example of chromosomes.

Table 1. Examples of Real-Coded in A Chromosome

\begin{tabular}{|l|l|l|l|l|}
\hline 5,1 & 4,7 & 3,8 & 6,1 & 7,9 \\
\hline
\end{tabular}

Each gene in a chromosome above represents the type of feed that declare the decision variables (x1, x2, and so on.) And the random number that represents the amount of feed to be given in kilograms. In addition to decision variables, there are also additional parameters attached to each chromosome that sigma $(\sigma)$. Sigma showed a mutation on chromosome level. The sigma value will change throughout generations adaptively. Examples of chromosomes along with additional variables and parameters as shown at Table 2.

Table 2. Example of Chromosome

\begin{tabular}{llllllll}
\hline $\mathbf{P}$ & $\mathbf{x}_{1}$ & $\mathbf{x}_{\mathbf{2}}$ & $\mathbf{x}_{\mathbf{n}}$ & $\boldsymbol{\sigma}_{\mathbf{1}}$ & $\boldsymbol{\sigma}_{\mathbf{2}}$ & $\boldsymbol{\sigma}_{\mathbf{n}}$ & $\mathbf{f}$ \\
\hline 1 & 5,1 & 4,7 & $\ldots$ & 0,2 & 0,6 & $\ldots$ & 21,3 \\
\hline
\end{tabular}

\section{b. Initialization}

Determining the initialization of chromosomes as population size (popSize) for the initial population. Writer determine popSize by 4 , so the initial population sample showed in Table 3.

Table 3. Example of Initial Population

\begin{tabular}{llllll}
\hline $\mathbf{P}$ & $\mathbf{x}_{1}$ & $\mathbf{x}_{2}$ & $\boldsymbol{\sigma}_{1}$ & $\boldsymbol{\sigma}_{2}$ & $\mathrm{f}$ \\
\hline 1 & 5,1 & 4,7 & 0,2 & 0,6 & 0,3 \\
2 & 2,7 & 9,2 & 0,3 & 0,5 & 0,4 \\
3 & 3,4 & 3,8 & 0,5 & 0,2 & 0,8 \\
4 & 7,6 & 2,7 & 0,4 & 0,7 & 0,5 \\
\hline
\end{tabular}

c. Reproduction

Reproduction process aims to produce child (offspring). In this study only carried the mutation alone so that the diversity of individuals in the population is maintained. In 
the process only takes one mutation of chromosomes as the parent. Let $\mathrm{P}=(\mathrm{x} 1, \mathrm{x} 2$, $\sigma 1, \sigma 1)$ are individuals who elected to transfer the resulting offspring $\mathrm{P}^{\prime}=(\mathrm{x} 1, \mathrm{x} 2, \sigma 1$, $\sigma 1)$ as follows:

$$
x^{\prime}=x+\sigma N(0,1)
$$

This formula can further be detailed as follows:

$$
\begin{aligned}
& x^{\prime}=x_{1}+\sigma_{1} N(0,1) \\
& x^{\prime}=x_{2}+\sigma_{2} N(0,1)
\end{aligned}
$$

$\mathrm{N}(0,1)$ is the random numbers that follow a normal distribution with an average of 0 and a standard deviation of 1 [11].

In computer programming, including JAVA, the value of $\mathrm{N}(0,1)$ obtained by generating two random numbers $\mathrm{r} 1$ and $\mathrm{r} 2$ on the interval $[0,1]$.

The formula used is as follows:

$$
N(0,1)=\sqrt{-2 \cdot \ln r 1 \sin 2 \pi r^{2}}
$$

Let $\mathrm{r} 1=0.47$ and $\mathrm{r} 2=0.33$ then obtained $\mathrm{N}(0,1)=1.071$.

If the fitness value mutated child better than the parent, the value of $\sigma$ is increased by the formula $\sigma^{\prime}=\sigma \times 1.1$. Meanwhile, if the child fitness value is not better than the parent then the value derived by the formula $\sigma \sigma^{\prime}=\sigma \times 0.9$.

d. Evaluation

The evaluation process aims to find out the good and bad of a chromosome to calculate the value fitnessnya. The formulation to calculate the value of fitness of this research are:

$$
\text { Fitness Value }=\frac{100000}{\operatorname{Sh}+(\operatorname{pp} \times 1000)+1}
$$

Description:

h: price

p: penalty

Here is an example of the calculation of $\mathrm{C} 1$ fitness for the child produced by parent P1

$$
\text { Nilai Fitness } C 1=\frac{100000}{240 n n n}=0,4016
$$

e. Selection

After conducting the evaluation process, the chromosome offspring ordered by the fitness value of the largest to the smallest. Then popSize chromosome number is taken to be a parent in the next generation. Such selection methods commonly referred to as the selection method elitism. 


\section{RESULTS AND DISCUSSION}

\subsection{Testing Scenario}

In this study, there are several test scenarios in order to obtain an optimal solution which is as follows:

a. Tests to determine the optimal size of population.

b. Tests to determine the optimal number of generation.

\subsection{Testing Results Analysis}

a. In testing this population using the generation of 100 . The test performed 10 times and then averaged.

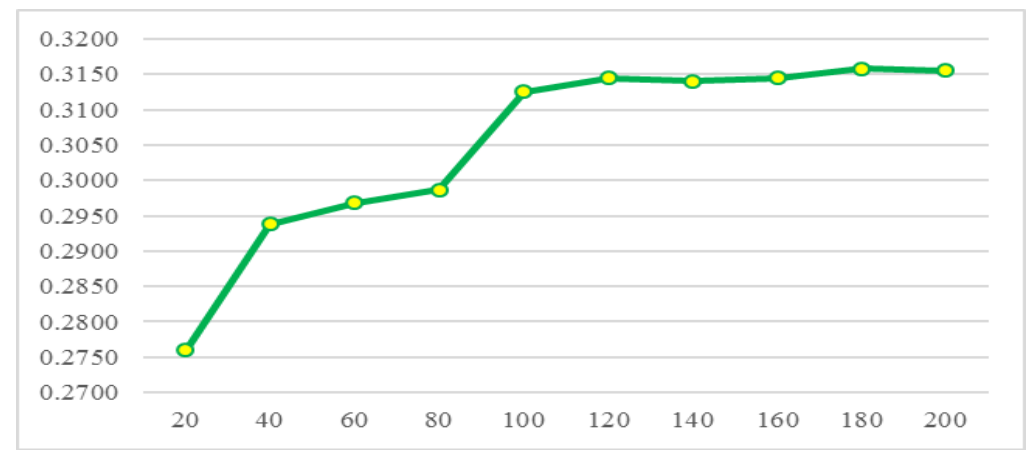

Figure 2. The Number of Population Testing Results

Can be seen in Figure 2, the highest fitness values found in the population size of 180 . However, due to population sizes ranging from 100 to 200 does not occur a significant increase, the authors take the population size of 100 as the size of the population to produce the optimal solution. In addition, the larger the population size, the more weight anyway computation process.

b. In testing this generation uses population size of 100 . The tests were conducted as much as $10 \mathrm{x}$ then be averaged as shown in Figure 3.

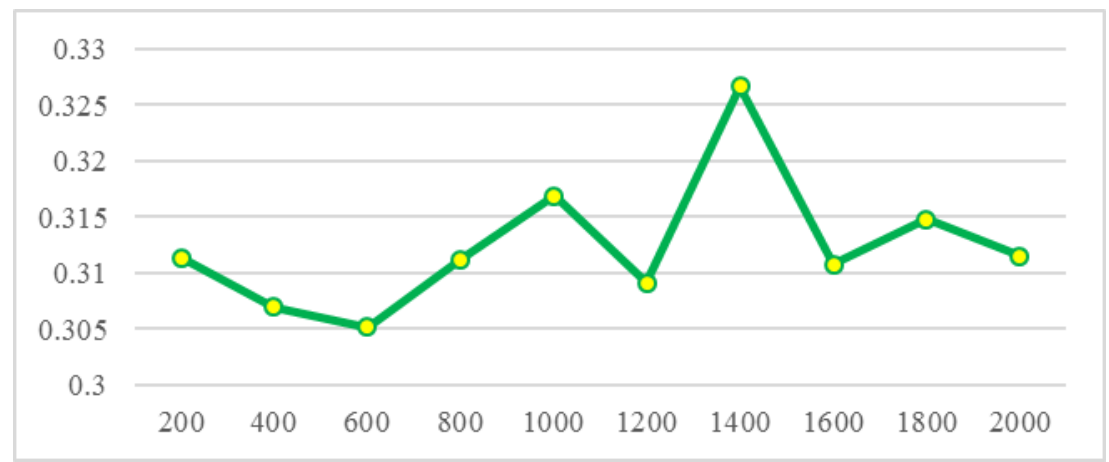

Figure 3. The Number of Generation Testing Results 
Can be seen in the graph, the highest fitness values are 0.3267 at the time of generation-1400.

\section{CONCLUSION}

Evolution Strategies can be applied to the optimization of the feed composition Lovebird. Producing the optimal solution with the fitness value of 0.3125 using the population size of 100 . Producing the optimal solution with the fitness value of 0.3267 contained in a generation- 1400 .

\section{REFERENCES}

[1] Immaduddin, T.F. 2013. Analisis Pengaruh Budidaya Burung Lovebird Terhadap Tingkat Pendapatan Pembudidaya di Kota Solo (Doctoral dissertation, Universitas Muhammadiyah Surakarta).

[2] Anonymous. Cara Budidaya Ternak Burung Lovebird Yang Baik dan Bagus. http://www.pehek.com/2013/06/cara-budidaya-ternak-burung-love-bird.html, accessed in Desember 25th 2016.

[3] Endarwati, D.U. and Hidayah, N. 2016. Dampak Budidaya Burung Lovebird Terhadap Kehidupan Sosial Ekonomi Masyarakat di Desa Banguntapan Bantul Yogyakarta. Universitas Negeri Yogyakarta, pp. 1-12.

[4] Fakhiroh, D and Mahmudy, W. F. 2017. Optimasi Komposisi Pakan Sapi Perah Menggunakan Algoritma Genetika. Jurnal Pengembangan Teknologi Informasi dan Ilmu Komputer Vol. 1, No. 1, pp. 69-74

[5] Ramadan, H. S., Bendary, A. F., and Nagy, S. 2017. Particle Swarm Optimization Algorithm for Capacitor Allocation Problem in Distribution Systems with Wind Turbine Generators. International Journal Electrical Power Energy System, vol. 84, pp. 143-152.

[6] Demiroz, G. and Yilmaz, C. 2016. Using simulated annealing for computing cost-aware covering arrays. Applied Soft Computing, vol. 49, pp. 1129-1144.

[7] Milah, H. and Mahmudy, W. F. 2015. Implementasi Algoritma Evolution Strategies Untuk Optimasi Komposisi Pakan Ternak Sapi Potong. DORO Repositori Jurnal Mahasiswa PTIIK Univ. Brawijaya, vol. 5, No. 11.

[8] Ashari, I. A. and Muslim, M. A. 2016. Comparison Performance of Genetic Algorithm and Ant Colony Optimization in Course Scheduling Optimizing. Scientific Journal of Informatics, vol. 3, No. 2, pp. 51-60.

[9] Marginingtyas, E. and Mahmudy, W. F. 2015. K Penentuan Komposisi Pakan Ternak Untuk Memenuhi Kebutuhan Nutrisi Ayam Petelur dengan Biaya Minimum Menggunakan Algoritma Genetika Vol 5 No. 12.

[10] Mahmudy, W. F. 2016. Dasar-Dasar Algoritma Evolusi. Universitas Brawijaya. 